\title{
PELATIHAN SPEAKING DENGAN MEDIA MINI DRAMA BAGI SISWA KELAS 5 SDN JOMBOR O1 BENDOSARI SUKOHARJO
}

\author{
Nurnaningsih $^{1)^{*}}$, Veronika Unun Pratiwi $^{2)}$, \& Arin Arianti ${ }^{3)}$ \\ ${ }^{1,2,3)}$ Program Studi Pendidikan Bahasa Inggris, Fakultas Keguruan dan Ilmu Pendidikan, Universitas \\ Veteran Bangun Nusantara Sukoharjo \\ *Corresponding author: nurnaninxnurna@gmail.com
}

Informasi Artikel

Terima: $13 / 01 / 2021$

Revisi : $31 / 03 / 2021$

Disetujui : 30/04/2021

Kata Kunci:

Pelatihan, Speaking, Minidrama

\section{ABSTRAK}

Bahasa Inggris merupakan salah satu mata pelajaran yang diajarkan di sekolah dasar (SD). Pengajaran bahasa Inggris ditingkat SD juga harus memperhatikan speaking karena salah satu unsurbahasa yang sangat penting adalah kosa kata (speaking). Penguasaan kosakata yang memadahi sangat diperlukan untuk keberhasilan penggunaan Bahasa (L2) karena tanpa penguasaan speaking yang memadahi kita tidak akan dapat menggunakan struktur dan fungsi-fungsi untuk berkomunikasi. Teknik yang tepat untuk menciptakan pengajaran bahasa Inggris yang efektif yaitu dengan menekankan perolehan speaking yang diperlukan untuk membantu siswa belajar tanpa ada rasa takut.

Metode yang digunakan dalam pengabdian ini dengan memakai media mini drama yang menarik perhatian siswa Kelas 5 SDN Jombor 1 Sukoharjo. Dimana kegiatan umum pelatihan ini diawali dengan penyuluhan untuk mengenalkan media yang dipakai dalam pembelajaran bahasa Inggris, terutama media yang menggunakan cerita yang menarik berwujud short dialog, mendengarkan rekaman short story mini drama secara daring dengan memberikan contoh cara mempergunakan mini drama untuk menambah kosakata baru bahasa Inggris, dilanjutkan dengan pendampingan mini drama dalam bahasa Inggris sampai dinilai siswa cukup mampu belajar secara mandiri, terakhir dengan melakukan evaluasi untuk mengetahui sejauh mana pengetahuan para siswa tentang materi speaking yang telah dipahami siswa.

Target yang ingin dicapai dari pengabdian ini adalah meningkatknya pengetahuan tentang penguasaan speaking bagi siswa Kelas 5 SDN Jombor 1 Sukoharjo. Luaran yang dicapai dari pengabdian ini adalah kemampuan berkomunikasi dalam Bahasa Inggris terkait dengan speaking. Penambahan kosakata baru dalam penguasaan speaking dalam Bahasa Inggris untuk dapat mengoptimalisasikan dan memaksimalkan aplikasi mini drama dalam kegiatan belajar mengajar sebagai bahasa rutin sehari-hari. 


\section{PENDAHULUAN}

Bahasa Inggris adalah bahasa internasional yang digunakan sampai saat ini. Karena pentingnya penggunaan bahasa Inggris, maka pemerintah Indonesia telah mempertimbangkan bahwa bahasa Inggris adalah bahasa asing yang pertama kali dipakai di Indonesia yang dianggap sangat penting untuk tujuan pengembangan ilmu pengetahuan, teknologi, dan budaya dan dipakai untuk membangun kerjasama internasional (Depdikbud, 1981).

Berdasarkan pertimbangan diatas, bahasa Inggris merupakan salah satu mata pelajaran yang diajarkan di sekolah dasar (SD).Tujuannya adalah untuk memberi motivasi serta menyiapkan siswa agar siap dan yakin dalam mempelajari bahasa Inggris ditingkat yang lebih tinggi, yakni SMP, SMA, serta Perguruan Tinggi.Meskipun demikian pengajaran bahasa Inggris di tingkat SD perlu untuk dilakukan, terutama pengajaran kosa kata (speaking). Alasan mengapa mengajar bahasa Inggris ditingkat SD juga harus memperhatikan speaking karena salah satu unsur bahasa yang sangat penting adalah kosa kata (speaking). Sebagaimana dikatakan oleh Rivers (1993 125), penguasaan kosakata yang memadahi sangat diperlukan untuk keberhasilan penggunaan Bahasa (L2) karena tanpa penguasaan speaking yang memadahi kita tidak akan dapat menggunakan struktur dan fungsifungsi untuk berkomunikasi.

Penguasaan speaking saja belumlah cukup karena speaking tidak akan berarti jika tidak disusun dengan kaidah tata bahasa yang tepat. Susunan kalimat yang telah memiliki kaidah tata bahasa yang tepat inipun perlu disusun dalam suatugenre (text type) yang memiliki suatu tujuan tertentu, generic structure dan lexicogrammatical features tertentu. Lexicogrammar disini meliputi Lexis (speaking) dangrammar. Selain itu, speaking tidak lepas dari pronunciation dimana pengajaran pronunciation ditingkat SD cukup sulit. Seperti pernyataan Rivers (1968) "This matter of acquition of a near native articulation and intonation by the students poses of the most difficult problems for teacher of certain languages."

Teknik yang tepat untuk menciptakan pengajaran bahasa Inggris yang efektif yaitu dengan menekankan perolehan speaking yang diperlukan untuk membantu siswa belajar tanpa ada rasa takut.Mengenai pendekatan komunikatif yang digunakan pada saat pengajaran speaking seharusnya mendukung/ menyokong elemenelemen lain dalam pengajaran bahasa Inggris. Selain itu penting untuk mengembangkan pengajaran speaking yang memadai, akan tetapi speaking bukanlah bagian dari pengajaran bahasa Inggris yang wajib diberikan di tingkat sekolah dasar. Meskipun speaking bukanlah pelajaran wajib yang harus diajarkan di bangku SD, guru seharusnya mengungkapkan kepada siswanya dengan lebih sering memperdengarkan suara atau mengulang suatu kata bahasa Inggris sebagai kebiasaan karena bahasa adalah sebuah sistem dari kebiasaan-kebiasaan. (Mackey, 1965:350)

Program Studi Pendidikan Bahasa Inggris adalah salah satu program studi milik Universitas Veteran Bangun Nusantara Sukoharjo. Program Studi ini adalah program studi termuda di FKIP Bantara Sukoharjo. Untuk melaksanakan salah satu tridarma perguruan tinggi yakni, pengabdian pada masyarakat, maka team pengabdian dari dosen prodi bahasa Inggris, mencoba membagi ilmu mereka untuk mengadakan pelatihan speaking bagi siswa SDN 01 Jombor Sukoharjo dengan menggunakan media yang sederhana yaitu gambar. 
SDN Jombor 01 Sukoharjo terletak di Jalan Tentara Pelajar no. 7 Kalurahan Jombor Kecamatan Bendosari Kabupaten Sukoharjo. SDN Jombor 1 Sukoharjo dipimpin oleh ibu Usdiyatmi. SD ini memiliki siswa yang jumlahnya fluktuatif naik turun karena kondisi pandemi ini, akan tetapi SDN Jombor 1 ini masih tetap menjadi sekolah favorit pilihan masyarakat, karena prestasi yang diraihnya. Namun tidak bisa dipungkiri kondisi ekonomi dari orangtua siswa ini bervariasi dari golongan ekonomi menengah kebawah. Orang tua siswa paling banyak hanya berpendidikan SMP dan SMA dan hanya sedikit yang berpendidikan sarjana (S1). Guru-guru yang mengajar di SDN Jombor 01 ini juga bervariasi ada guru negeri (PNS) dan ada guru tidak tetap (GTT).

Dalam pembelajaran bahasa khususnya pembelajaran bahasa Inggris, terdapat empat keterampilan berbahasa yang mutlak harus dikuasai oleh siswa, yaitu keterampilan menyimak (listening), keterampilan membaca pemahaman (reading), keterampilan berbicara (speaking), dan keterampilan menulis (writing) serta kemampuan kosakata dan grammatik (Structure and speaking). Suatu keterampilan akan dikuasai dengan baik jika dibelajarkan dan dilatihkan. Demikian pula halnya dengan kemampuan penguasaan kosakata perlu dibelajarkan. Penguasaan kosakata yang baik dan kontinu sangat dibutuhkan mengingat pentingnya dengan keterampilan berbahasa lainnya. Penguasaan kosakata merupakan salah satu aspekbahasa yang perlu dikaji. Keterampilan penguasaan kosakata setidaknya mampu menjadi penunjang dan sebagai ukuran bagi individu dalam mempelajari suatu bahasa serta bersifat primer dalam menjalin komunikasi antar individu.

Siswa Kelas 5 SD Negeri Jombor 1 Sukoharjo yang berjumlah 24 siswa pada pembelajaan bahasa Inggris menuntut para siswa terampil berbicara dalam proses pembelajaran. Para siswa setidaknya mampu mengutarakan gagasannya, mampu menjawab pertanyaan atau mengajukan pertanyaan, mengemukakan pendapat, mempertahankan pendapat, menyanggah pendapat siswa lain, atau mempengaruhi siswa lain agar mengikuti alur pemikirannya. Hal tersebut dipengaruhi oleh sejauh mana penguasaan speaking siswa dan seberapa banyak speaking yang bisa diproduksi dalam mengungkan suatu gagasan. Namun berdasarkan data empiris menunjukkan bahwa siswa yang telah mempelajari bahasa Inggris masih tergolong rendah. Prestasi belajar para siswa di SDN Jombor 01 ini rata-rata bagus secara umum tapi untuk pelajaran bahasa Inggris hanya beberapa siswa yang mendapat nilai bagus. Keberanian siswa untuk maju didepan kelaspun nampak rendah karena kebanyakan mereka takut berbuat salah ketika mengucapkan kata dalam bahasa Inggris. Permasalahan seperti inilah yang membuat tim pengabdian masyarakat tertarik untuk melakukan pembinaan terutama pelatihan penguasaan kosakata (speaking) berbahasa Inggris dengan menggunakan gambar sebagai media yang sederhana dan mudah sehingga diharapkan siswa menjadi tertarik untuk belajar bahasa Inggris.

\section{SOLUSI YANG DITAWARKAN}

Sehubungan dengan permasalahan diatas maka tim pengabdian pada masyarakat mengambil langkah dengan mengadakan pelatihan kosakata (speaking) dengan memakai media gambar - gambar (kartu huruf bergambar) yang menarik perhatian siswa Kelas 5 SDN Jombor 1 Sukoharjo. Dimana kegiatan umum pelatihan ini diawali dengan penyuluhan 
untuk mengenalkan media yang dipakai dalam pembelajaran Bahasa Inggris, terutama media yang menggunakan short story yang menarik, demonstrasi dengan memberikan rekaman suara dialog mini drama yang berupa short story yang menarik untuk menambah kosakata baru bahasa Inggris, dilanjutkan dengan pendampingan menggunakan media dalam bahasa Inggris sampai dinilai siswa cukup mampu belajar secara mandiri, terakhir dengan melakukan evaluasi untuk mengetahui sejauh mana pengetahuan para siswa tentang materi speaking yang telah dipahami siswa.

\section{Penyuluhan}

Mengadakan observasi awal atau orientasi lapangan mengenai pengetahuan siswa-siswi SD Negeri Jombor 01 Sukoharjo tentang pengetahuan bahasa Inggris. Pemberian materi dengan cara mengenalkan media yang dipakai dalam pembelajaran bahasa Inggris, terutama media yang menggunakan IT serta member penjelasan pada para siswa akan apa yang dilakukan oleh tim pengabdian dilakukan oleh Veronika Unun Pratiwi, S.Pd., M.Pd., selama kurang lebih 30 menit.

\section{Demonstrasi}

Pengabdian ini berupa memberikan pelatihan tentang penguasaan speaking dalam Bahasa Inggris dengan menggunakan media mini drama. Menurut Wendy A. Scott dan Lisbeth $\mathrm{H}$. dialog dan memainkan peran dalam sebuah lakon adalah kegiatan oral yang berguna. Mini drama merupakan strategi pembelajaran yang menggunakan short story dialog sebagai media pembelajaran, dialog dalam mini drama ini menjadi perangkat utama dalam proses pembelajaran. Kegiatan ini dilakukan oleh Nurnaningsih, S.Pd., M.Pd. Langkah-langkah penerapan strategi Mini drama adalah sebagai berikut:

a. Tahap 1: PenyampaianKompetensi

Pada tahap ini guru diharapkan menyampaikan kompetensi dasar mata pelajaran yang bersangkutan. Siswa dapat mengukur sampai sejauh mana kompetensi yang harus merekakuasai. Guru juga harus menyampaikan indicator - indikator ketercapain kompetensi untuk mengukur tingkat keberhasilan siswa dalam mencapainya.

b. Tahap 2: Presentasi Materi

Pada tahap penyampaian materi, guru telah menciptakan momentum awal pembelajaran. Pada tahapini, guru harus berhasil memberimotivasi pada beberapa siswa yang kemungkinan belumsiap.

c. Tahap 3: Penyajian Gambar

Pada tahapini, guru menyajikan gambar dan mengajak siswa untuk terlibat aktif dalam proses pembelajaran dengan mengamati setiap gambar yang ditunjukkan. Dengan gambar, pengajaran akan hemat energy, dan siswa juga akan lebih memahami materi yang diajarkan. Dalam perkembangan selanjutnya, guru dapat memodifikasi short story atau menggantinya dengan rekaman atau demonstasi kegiatan tertentu.

d. Tahap 4: Pemasangan Gambar

Pada tahap ini, guru menunjuk atau memanggil siswa secara bergantian untuk mempraktekkan dialog mini drama dari short story yang diberikan oleh guru.

e. Tahap 5: Penjajakan

Pada tahap ini mengharuskan guru menanyakan kepada siswa tentang alasan/dasar pemikiran di balik memahami dialog mini drama. Setelah itu siswa diajak menemukan kosakata baru yang mereka dapatkan dari membaca dialog short story mini drama.

f. Tahap 6: PenyajianKompetensi

Dalam proses ini, guru harus memberikan penekanan pada 
ketercapaian kompetensi tersebut. Guru dapat mengulangi, menuliskan, atau menjelaskan gambar-gambar tersebut agar siswa mengetahui bahwa sarana tersebut penting dalam pencapaian kompetensi dasar dan indikatorindikator yang telah ditetapkan.

g. Tahap 7: Penutup

Di akhir pembelajaran, guru dan siswa saling berefleksi mengenai apa yang telah dicapai dan dilakukan. Hal ini dimaksudkan untuk memperkuat materi dan kompetensi siwa dalam mengingat.

\section{Pendampingan}

Pendampingan dilakukan selama empat bulan mulai dari bulan Juli sampai Oktober 2020. Tim Pengabdian melakukannya secara daring ke SDN Jombor 01 di mana mitra belajar, kegiatan ini dilakukan secara rutin.

\section{Evaluasi}

Evaluasi dilakukan dengan pretest dan post-test. Pre-test menggunakan questionnaire untuk mengetahui sejauh mana pengetahuan para siswa tentang materi speaking yang telah mereka pahami, dilakukan oleh Nurnaningsih, S.Pd., M.Pd yang dilaksanakan selama 15 Menit. Sementara itu setelah dilakukan penyuluhan dan pelatihan, tim pengabdian melakukan evaluasi dengan menggunakan questionnaire untuk mengetahui adanya kemajuan dan peningkatan pengetahuan para siswa tentang pemahaman materi tentang speaking, dilakukan oleh Arin Arianti, S.Pd., M.Pd., selama15 Menit.

\section{HASIL DAN PEMBAHASAN}

\section{A. Hasil}

Keterampilan berbicara dengan menggunakan bahasa Inggris bagi siswa usia sekolah dasar sangat diperlukan mengingat keterampilan tersebut dapat membantu siswa berkomunikasi dengan orang lain baik di dalam maupun di luar sekolah. Pada kenyataannya keterampilan inilah yang dibutuhkan para siswa sekolah dasar untuk dapat diterima di sekolah lanjutan. Suatu keterampilan akan dikuasai dengan baik jika dibelajarkan dan dilatihkan. Pembelajaran keterampilan berbicara (Speaking) yang baik dan kontinu sangat dibutuhkan mengingat pentingnya keterampilan berbahasa lainnya. Selain speaking, para siswa juga dituntut untuk bisa menguasai skills lain dalam bahasa Inggris yaitu writing, reading, dan listening. Namun yang terpenting dari semua itu adalah para siswa mampu menguasai speaking dengan baik dan benar, meskipun dalam tingkatan yang sederhana.

Hasil evaluasi tentang pelatihan Speaking dengan media mini drama ini bisa dilihat dari hasil pretest dan posttest, serta dari hasil pelatihan dan pendampingan. Anak-anak yang semula pasif begitu melihat media yang dipakai oleh tim pengabdian mereka menjadi begitu antusias untuk mengikuti pelajaran bahasa Inggris. Dari empat kali pelatihan dan pendampingan oleh tim pengabdi, bisa dilihat bahwa hasil belajar speaking para siswa cenderung baik di atas $\mathrm{kkm}(7,5)$.

\section{B. Pembahasan}

Kegiatan Pengabdian Kepada Masyarakat dalam bentuk penyuluhan dan demonstrasi / percontohan tentang pelatihan speaking dengan mini drama. Hal ini terkait dengan keterampilan berbicara, mendengarkan, menulis, serta membaca siswa SD yang masih jauh dari harapan. Pelatihan speaking dengan media mini drama ini sangat membantu guru dan siswa, terutama para siswa menjadi tertarik dengan media mini drama yang dilandasi dari cerita pendek yang sudah dikenal oleh siswa. Tim pengabdi mengajak para siswa untuk berdialog berdasarkan cerita yang sudah disediakan oleh team pengabdi, baik dengan media mini drama. Mereka sangat antusias mengikuti pelatihan ini. Namun ada beberapa siswa yang kurang 
begitu memperhatikan, mereka merasa malu, sehingga duduk diam tidak bereaksi. Oleh karena itu kegiatan pelatihan ini sangat membantu para peserta. Secara umum kegiatan ini sangat bermanfaat dalam pembelajaran bahasa Inggris sehari-hari. Keberhasilan ini tidak lepas dari adanya dukungan kepala sekolah, guru dan karyawan SD Negeri Jombor 01. Selain itu keinginan peserta untuk menguasai pelatihan speaking ini cukup besar. Pengetahuan tentang pelatihan speaking ini belum pernah diterima oleh peserta, sehingga mereka antusias sekali dalam mengikuti kegiatan kegiatan pelatihan.

Dalam pelaksanaan kegiatan pelatihan ini, tim pengabdi melakukan hal-hal sebagai berikut:

1. Mengadakan observasi awal atau orientasi lapangan mengenai pengetahuan siswa-siswi SD Negeri Jombor 01 Sukoharjo tentang pengetahuan bahasa Inggris. Pada observasi awal, tim pengabdi mendapati kemampuan penguasaan speaking siswa kelas 5 dirasa masih jauh dari harapan. Hal ini dilihat dari rekaman nilai siswa yang masih di bawah KKM.

2. Mengadakan pretest mengenai kemampuan penguasaan speaking siswa-siswi SD Negeri Jombor 01 Sukoharjo dalam bahasa Inggris. Hasil dari pretest menunjukkan bahwa rata-rata kemampuan siswa adalah 65,42 \% yaitu masuk rentangan kategori nilai sedikit paham.

3. Memberikan pelatihan tentang kemampuan menguasai kosa kata bahasa Inggris, dengan media mini drama. Adapun prosedur pembelajarannya adalah sebagai berikut:

- Tim pengabdi menjelaskan materi dengan media gambar nyata atau realia serta LCD. Peserta terlihat lebih antusias karena disajikan gambar sesuai dunia mereka. (dilakukan oleh Veronika dibantu mahasiswa)

- Tim pengabdi memberikan contoh penguasaan speaking dengan picture to picture yang sederhana dalam kehidupan sehari-hari. (dilakukan oleh Nurna, Arin dibantu oleh mahasiswa)

- Dilakukan pretest dan post test untuk mengetahui sejauh mana kemampuan siswa dalam penguasaan speaking (dilakukan oleh Arin, Veronika, dibantu mahasiswa)

- Dilakukan evaluasi, untuk mengetahui hasil dari pelatihan speaking dengan media mini drama (dilakukan oleh Nurna dibantu oleh 2 mahasiswa)

- Tim pengabdi memberikan rekaman dialog short story dalam bahasa Inggris, siswa mendengarkan. (Dilakukan oleh mahasiswa)

- Setelah siswa cukup mampu menguasai speaking yang ada mereka diminta maju berpasangan untuk praktek menggunakan speaking dengan media mini drama (dilakukan oleh semua tim pengabdi; Arin, Veronika, Nurna, dan dibantu 2 mahasiswa).

Faktor penghambat dari kegiatan ini relatif kecil, dari 24 siswa tampak ada 3 siswa yang terlihat kurang tertarik dengan materi sehingga nilai pre testnya di bawah KKM, namun setelah pelatihan nilai mereka mengalami peningkatan, selain juga kendala sinyal dan HP yang mereka miliki bergantung pada orang tua mereka. Namun segala kendala bisa diatasi dengan baik dengan bantuan sekolah.

Para peserta merasa senang karena dengan teknologi yang ada yaitu mendengarkan short dialog drama da 
memprakrekkannya, serta mengenal kosakata baru dalam Bahasa Inggris.

Dari hasil evaluasi didapatkan siswa mulai berinteraksi aktif meskipun secara daring, pihak sekolah juga mendukung kegiatan ini, karena konsisi pandemi yang mengharuskan semua KBM dilakukan secara daring. Hasil yang didapatkan dari nilai rerata 65,42 naik menjadi 90,83, dan siswa merasa senang dengan hasil yang mereka peroleh.

Hal ini menunjukkan bahwa kegiatan pengabdian kepada masyarakat berhasil meningkatkan pengetahuan peserta tentang penguasaan speaking. Hal ini juga menunjukkan bahwa peserta dalam mengikuti pelatihan sangat antusias. Luaran yang dihasilkan dalam kegiatan ini adalah, kemampuan siswa-siswi SD Negeri Jombor 01 Sukoharjo khususnya siswa kelas 5 dalam penguasaan speaking secara sederhana dengan media mini drama.

\section{KESIMPULAN}

\section{A. Kesimpulan}

Dari kegiatan pengabdian pada masyarakat ini dapat disimpulkan bahwa pelatihan tentang penggunaan speaking dengan media mini drama dapat meningkatkan minat serta motivasi siswa dalsam pembelajaran bahasa Inggris sejak di bangku sekolah dasar. Hal ini bisa dilihat melalui hasil post test atau hasil evaluasi siswa yang meningkat.

\section{B. Saran}

(1) Peserta pengabdian diharapkan tetap meneruskan pelatihan speaking ini meskipun sudah tidak lagi didampingi oleh tim pengabdian. (2) Guru kelas khususnya guru bahasa Inggris diharapkan menciptakan inovasi-inovasi baru dalam pembelajaran sehingga siswa tidak merasa bosan. (3) Perlu dilakukan kegiatan serupa di wilayah lain, sehingga para siswa SD negeri pada umumnya dapat memahami dan mengaplikasikan hasil pembelajaran yang telah mereka dapatkan di jenjang pendidikan yang lebih tinggi yakni di bangku SMP.

\section{DAFTAR PUSTAKA}

Brown, Douglas H. (1987). Principle of Language Learning and Teaching.Englewood Cliffs, New Jersey: Prentice Hall Regents.

Hymes, Dell. (1988). Foundation in Sociolingusitics: an Etnographic Approach.Philadelphia:

University of Pennsylvania Press.

Rivers,W. (1993). Communicating Naturally in a Second Language. Cambridge: Cambridge UniversityPress.

Wardhaugh, Ronald. (1998). An Introduction to Sociolinguitics. Oxford: Blackwell Publishers Ltd.

Widdowson, Henry G. (1978). Teaching Language as Commnuication. Oxford: OxfordUniversity Press.

www.sil.org/lingualinks/language learning/other reources/gudlns FrAl./11/200 